\title{
THE EFFECT OF INSTRUCTIONAL, TRANSFORMATIONAL AND SPIRITUAL LEADERSHIP ON ELEMENTARY SCHOOL TEACHERS' PERFORMANCE AND STUDENTS' ACHIEVEMENTS
}

\author{
Ahmad Nurabadi ${ }^{1,2 *}$, Jusuf Irianto ${ }^{1}$, Ibrahim Bafadal ${ }^{2}$, Juharyanto ${ }^{2}$, \\ Imam Gunawan ${ }^{2}$, Maulana Amirul Adha ${ }^{2}$ \\ ${ }^{1}$ Universitas Airlangga Surabaya, Indonesia \\ ${ }^{2}$ Universitas Negeri Malang, Indonesia \\ *e-mail: ahmad.nurabadi.fip@um.ac.id
}

\begin{abstract}
Persistence for achievement reflected from the willingness and determination of principal to implement quality leadership will facilitate the improvement of teachers' performance, and the two will be the determinant factors for the students' ultimate achievement. This study aims at analyzing empirical data on the effect of instructional, transformational and spiritual leadership as independent variables, with school quality as the dependent variable. In addition, the intervening variable is teachers' performance. This study employed the quantitative approach in which samples of 181 teachers were re taken using the proportional random sampling technique. All data were then analysed using the SEM technique with the AMOS 24 application. The findings show that: (1) there is a direct effect of instructional leadership on teachers' performance, transformational leadership on teachers' performance, spiritual leadership on teachers' performance, instructional leadership on students' achievement, transformational leadership on students' achievement, spiritual leadership on students' achievement, and teachers' performance on students' achievement. In addition, (2) there is an indirect effect of instructional leadership on students' achievement through teachers' performance, transformational leadership on students' achievement through teachers' performance and spiritual leadership on students' achievement through teachers' performance.
\end{abstract}

Keywords: instructional leadership, transformational leadership, spiritual leadership, teachers' performance, students'achievement.

\section{PENGARUH KEPEMIMPINAN PEMBELAJARAN, PERUBAHAN, DAN SPIRITUAL TERHADAP KINERJA GURU DAN PRESTASI SISWA SEKOLAH DASAR}

\begin{abstract}
Abstrak: Kesungguhan berprestasi yang ditunjukkan oleh kemauan dan kesanggupan kepala sekolah dalam menerapkan kepemimpinan yang berkualitas akan memfasilitasi tumbuh dan berkembangnya kinerja guru, dan keduanya menjadi penentu keberhasilan belajar peserta didik secara maksimal. Penelitian ini bertujuan untuk menganalisis informasi empiris pengaruh kepemimpinan pembelajaran, kepemimpinan perubahan dan kepemimpinan spiritual kepala sekolah yang ditetapkan sebagai variabel bebas. Mutu sekolah, ditetapkan sebagai variabel terikat. Sementara kinerja guru ditetapkan sebagai variabel intervening. Penelitian ini menggunakan pendekatan kuantitatif, dengan jumlah sampel sebanyak 181 guru diambil menggunakan teknik proportional random sampling. Seluruh data dianalisis degan teknik SEM dengan bantuan aplikasi AMOS 24. Hasil penelitian menunjukkan: (1) ada pengaruh secara langsung kepemimpinan pembelajaran terhadap kinerja guru, kepemimpinan perubahan terhadap kinerja guru, kepemimpinan spiritual terhadap kinerja guru, kepemimpinan pembelajaran terhadap prestasi siswa, kepemimpinan perubahan terhadap prestasi siswa, kepemimpinan spiritual terhadap prestasi siswa, dan kinerja guru terhadap prestasi siswa, (2) ada pengaruh secara tidak langsung kepemimpinan pembelajaran terhadap prestasi siswa melalui kinerja guru, kepemimpinan perubahan terhadap prestasi siswa melalui kinerja guru, dan kepemimpinan spiritual terhadap prestasi siswa melalui kinerja guru.
\end{abstract}

Kata Kunci: kepemimpinan pembelajaran, kepemimpinan perubahan, kepemimpinan spiritual, kinerja guru, prestasi siswa. 


\section{INTRODUCTION}

Persistence for achievement reflected from willingness and determination of principal to implement quality leadership facilitates the improvement of teachers' performance and the two will be determinant factors for students' ultimate achievement (Mulyani, Meirawan, \& Rahmadani, 2020). Principal plays significant role for school development. Therefore, he should have willingness and persistence to encourage, ask, drive, moves, guide and direct all school stakeholder for the sake of school development (Blome \& James, 1985; Murakami, Garza, \& Merchant, 2012; Jäppinen, Leclerc, \& Tubin, 2016). In addition, principals bear significant responsibilities. He is responsible for determining school future, for creating conducive environment to nurture potentials of teachers, students and school staffs (Adair, 2007; Bezzina, 2000). The conducive atmosphere is crucial for improving teachers' performance. Teachers plays significant role for national development and they are also determinant factor to achieve education objectives (Min, Modeste, Salisbury, \& Goff, 2016; Stones, 2003). It is because teachers are the spirit of schools (Kalman \& Arslan, 2016).

Teachers' role is also significant to produce high quality graduates. Thus in order to produce high quality graduates, there should be teachers of high quality performance (de Lima \& dos Passos, 2015; Wong, 2004). In addition, teachers might show high quality performance if they are under good leadership. Teachers are one of the humane components in instructional process playing significant role in creating qualified human resources for national development (Bezzina, 2000; García-Vázquez, Crespi, \& Riccio, 2010). High quality performance facilitates teachers to achieve predetermined goals. Achieving goals of improving teachers' performance ensures the achievement of quality improvement of national education (Heck \& Hallinger, 2014; Min et al., 2016).

Leadership model of principal is crucial factor in effective development of school (Yakavets, 2016). Overall achievement of school is influenced by principal leadership (Bendikson, Robinson, \& Hattie, 2012). There is a need for principle to turn himself to be either direct or indirect instructional leader in order to improve instructional achievement (Bendikson et al.,
2012; Pan, Nyeu, \& Chen, 2015). Several studies showed that proper instructional leadership gives significant effect on teachers' performance and students' achievement (Kusmintardjo, 2014; Nguyen, Ng, Luo, \& Mansor, 2020). Instructional leadership is planned efforts to create productive and conducive working atmosphere for teachers and comfortable condition for students' learning (Blase \& Blase, 2000; Neumerski 2013). Instructional leadership of principals is reflected from the ability of principals to state clear school vision and mission, to focus on instruction and to create conducive working environment (Hallinger, 2009; Rigby, 2014). Instructional leadership is crucial because it will facilitate the development of school as learning community and even learning school as well as learning society/community (Bush, 2015; Carpenter, 2015).

Currently, leadership and transformation adaptation are two crucial challenge faced by leader (Tang, Lu, \& Hallinger, 2014). Transformational leadership emphasizes on principal efforts to design innovative and adaptive school program to keep up with changing environment and to achieve students' learning achievement (Heystel \& Emekako, 2020; Suryadi \& Tinov, 2013). As instructional leader, principal should be able to identify teachers and students need to help them take part in instructional process. In addition, principals should take all factors influencing instructional process into serious account especially those related to changes on instructional environment (Kin, Kareem, Nordin, \& Bing, 2018). He should also be able to design strategic transformational program. The strategic steps for transformation should be the guidance to anticipate future challenges. Therefore, by transformational leadership principals might give positive contribution to improve students' learning achievement (Tang et al., 2014; Wiyono, 2017; Hidayat, \& Wulandari, 2020).

Transformational leadership influences development process, school change and teachers' performance during instruction (Wiyono, 2017; Taylor, Goeke, Klein, Onore, \& Geist, 2011). Principal should implement transformational leadership in order to keep up with science development which influence every aspect of life at school. Principal, as transformation leader, is responsible for 
managing those transformation (Kasali, 2007). Therefore, transformational leadership is significant attribute for principal to encourage teachers' performance during transformation to improve students' achievement.

Principals should not only focus on instruction for students, or the task of teachers or staffs. They should also find a way how to make students, teachers and school task do their task responsibly (Fry, Latham, Clinebell, \& Krahnke, 2017; Gibson, 2014). Principals are not only leader of school but also spiritual leader for school community or society (Hyson, 2013). Principals should also possess moral and religious spiritual values as those reflected in personal competence. During digital era, it is crucial for principal to take active role as spiritual leader for school member (Cheng, Ko, \& Lee, 2016; Brinia, Zimianiti, \& Panagiotopoulos, 2014).

Spiritual leadership is combination of attitude, values and behaviour of leaders which are needed to encourage themselves or others (Avalio \& Gardner, 2005; Fry, 2003, 2005; Hyson, 2013). Spiritual leadership of principal is reflected from his action and attitude. Spiritual leadership inspires, encourages, influences and drives others by giving example (Gibson, 2014). Superior principal should be role model for his subordinates. Principals' modality to internalize positive values to all school stakeholders is his success in spiritual leadership giving concrete contribution on the improvement of teachers' performance and students' achievement in either academic or non-academic aspects (Fry et al., 2017; Sheikh, Inam, Rubab, Najam, Rana, \& Awan, 2019). Future leader is characterised by his effort to be role model and to communicate his leadership through his actions (Brown \& Trevino, 2006) which is called resonant leadership (Boyatzis \& McKee, 2006). Based on the afore-mentioned background, this study aims at analysing empirical data on the effect of instructional, transformational, and spiritual leadership of functioning as independent variables. In addition, school quality is dependent variable and the intervening variable is teachers' performance.

\section{Proposed Theoretical Model}

Figure 1 shows theoretical model proposed in this study. It covers the effect of instructional, transformational and spiritual leadership and teachers' performance on students' achievement at elementary school.

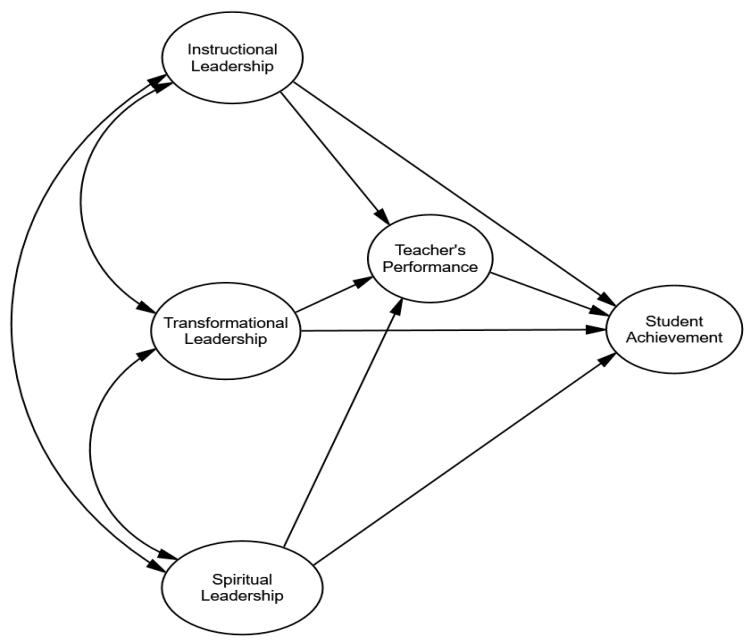

Figure 1. Model of Theoretical Framework

\section{METHODS}

Population and Sample

This study employs quantitative approach of expost-facto. The writers do not control directly the independent variables because the events have occurred (Creswell, 2014; Saunders, Lewis, \& Thornhill, 2016). The population is elementary school teachers at Malang (including Kota Malang, Kota Batu and Kabupaten Malang). Samples are taken by using proportional random sampling technique because this technique allows the researcher to obtain samples which are proportional to the number of population. The population in this study were 15,101 teachers, using the Slovin formula, the overall sample in this study was 181 respondents, as shown in Table 1.

Table 1. Population and Sample

\begin{tabular}{llrc}
\hline No. & City/Regency & Population & Sample \\
\hline 1 & Kota Malang & 4,084 & 49 \\
2 & Kota Batu & 914 & 11 \\
3 & Kabupaten Malang & 10,103 & 121 \\
\hline Total & 15,101 & 181 \\
\hline
\end{tabular}

\section{Data Collection Instrument}

Instrument used to gather data is close-ended questionnaire. Questionnaire for instructional leadership (IL), transformational leadership (TL) and spiritual leadership (SL) and teachers' performance (TP) are developed based on theories underlying research variables 
(Creswell, 2014; Wiyono 2007), as shown in Table 2. Furthermore, the last three-year scores of national examination, achievement for national science Olympic (academic achievement) and achievement of national sport Olympics, art festival and competition (non-academic) are used to measure students' achievement (SA) variable. The instruments must be valid and reliable.

To measure the validity level of instruments items, using the analysis of the validity of Aiken's V. Aiken (1985) formulated the Aiken's V formula to calculate the contentvalidity coefficient which is based on the results of the assessment of an expert panel of $n$ people on an item in terms of the extent to which the item represents the construct being measured. Based on the Aiken's V validity test, the Aiken's $\mathrm{V}$ coefficient ranges for each variable are as follows, (a) IL: .664 - .811, (b) TL: .613 - .719, (c) SL: .660 - .748, and (d) TP: .610 - .811. Based on the Aiken's V value, all items in the instrument are declared valid and suitable for use in further research (Azwar, 2012). Then, reliability test was conducted, the test was conducted by using cronbach's alpha with SPSS 24.0 software. Specifically, the scores are (1) IL: .842, (b) TL: .868 , (c) SL: .917 and (d) TP: .948. Based on this value the instrument can be declared reliable.

Table 2. Variable and Indicator

\begin{tabular}{|c|c|c|}
\hline Variable & Indicator & Item \\
\hline \multirow[t]{6}{*}{$\begin{array}{l}\text { Instructional } \\
\text { Leadership } \\
\text { (IL) }\end{array}$} & $\begin{array}{l}\text { 1. To be able to understand, explain, and equate the } \\
\text { vision, mission, goals and targets of the school } \\
\text { (visioning of learning) }\end{array}$ & $1,2,3,4$ \\
\hline & $\begin{array}{l}\text { 2. To be able to understand, explain, and equate the } \\
\text { vision, mission and objectives with the school's } \\
\text { flagship program (visioning of learning) }\end{array}$ & $5,6,7$ \\
\hline & $\begin{array}{l}\text { 3. To be able to developing a new learning culture in } \\
\text { accordance with the demands of the curriculum }\end{array}$ & 8,9 \\
\hline & $\begin{array}{l}\text { 4. To be able to developing an effective learning } \\
\text { environment }\end{array}$ & 10 \\
\hline & $\begin{array}{l}\text { 5. To be able to strive to support the school committee } \\
\text { well in supporting the learning program }\end{array}$ & 11 \\
\hline & $\begin{array}{l}\text { 6. To be able to strive for a process to ensure the } \\
\text { success of implementing learning programs }\end{array}$ & $12,13,14$ \\
\hline \multirow{4}{*}{$\begin{array}{l}\text { Transformational } \\
\text { Leadership } \\
\text { (TL) }\end{array}$} & 1. To be able to looking to the future and designing & 1,2 \\
\hline & $\begin{array}{l}\text { changes to anticipate the future (visionary) } \\
\text { 2. To be able to inspire teachers to look to the future to } \\
\text { make changes }\end{array}$ & $3,4,5,6$ \\
\hline & $\begin{array}{l}\text { 3. To be able to establish transformational strategic } \\
\text { steps }\end{array}$ & $7,8,9$ \\
\hline & $\begin{array}{l}\text { 4. To be able to implementation of changes } \\
\text { 5. To be able to evaluating changes and planning } \\
\text { follow-un }\end{array}$ & $\begin{array}{l}10,11,12 \\
13,14,15,16\end{array}$ \\
\hline \multirow{4}{*}{$\begin{array}{l}\text { Spiritual } \\
\text { Leadership } \\
\text { (SL) }\end{array}$} & 1. Hard work based on responsibility & $1,2,3$ \\
\hline & 2. Discipline & $4,5,6,7$ \\
\hline & 3. Honesty & 8,9 \\
\hline & $\begin{array}{l}\text { 4. Axemplary } \\
\text { 5.ways be grateful for every success and failure } \\
\text { based on sincerity and patience }\end{array}$ & $13,14,15$ \\
\hline \multirow{4}{*}{$\begin{array}{l}\text { Teacher's } \\
\text { Performance } \\
\text { (TP) }\end{array}$} & 1. To be able to prepare a lesson plan & $1,2,3,4,5,6,7$ \\
\hline & 2. To be able to carry out learning & $\begin{array}{l}8,9,10,11,12,13, \\
14,15,16,17,18, \\
19,20,21,22,23, \\
24,25,26,27\end{array}$ \\
\hline & $\begin{array}{l}\text { 3. To be able to evaluating the learning process and } \\
\text { results }\end{array}$ & \\
\hline & $\begin{array}{l}\text { 4. To be able to organizing follow-up learning } \\
\text { programs }\end{array}$ & $29,30,31,32,33,34$ \\
\hline
\end{tabular}




\section{Data Analysis}

In this study, data are analysed by using path analysis. In line with objectives of study, the researcher uses AMOS 24.0 for CFA and SEM. Before conducting a full SEM analysis model, the data normality test and the outliers test are firstly performed. Testing assumptions in SEM is the preliminary evaluation criteria stage (Byrne, 2016) where the most crucial key assumption, if the maximum likelihood (ML) estimation is used is data normality. Evaluation of data normality was carried out using a critical ratio skewedness value of \pm 2.58 at a significance level of .05 $(5 \%)$. The data is said to be normally distributed if the critical ratio skewedness value is below \pm 2.58 (Ghazali, 2011). The outlier test is carried out to see the observation conditions of data that have unique characteristics that look very different from other observations and appear in extreme forms, both for single variables or for combined variables (Hair, Black, Babin, \& Anderson, 2010). Outlier test is done to see univariate outliers and also multivariate outliers. In order to see the multivariate outliers, it is done by looking at the Malahanobis distance value. The Malahanobis distance value is compared to the chi-square value, if the Malahanobis distance value ( $>$ chi-square) means there is a multivariate outlier problem (Ghazali, 2011).

Modelling of SEM structural equation was conducted by using SEM AMOS 24. This method helps researcher to compose complex effect model that might be used to analyse direct and indirect effect (Byrne, 2016; Hair et al., 2010; Parco-Tropicales \& de Guzman, 2014). Measurement model is used to elaborate and evaluate indicators of validity and reliability to assess hypothetical construct. Furthermore, structural model is for elaborating inter variables contribution which are not observed and related to the effect of inter variables based on proposed hypothesis (Al-husseini \& Elbeltagi, 2018; Hair et al., 2010).

Evaluation of the measurement model in this study was carried out by confirmatory factor analysis (CFA). Evaluation of the goodness of fit criteria is an evaluation of the feasibility test of a model with several criteria for the suitability of the index and its cut of value, in order to state whether a model can be accepted or rejected. In summary, the criteria for the Goodness of Fit Index, (Ghazali, 2011; Hair et al., 2010) are summarized in Table 3.

Tabel 3. Goodness of Fit Index

\begin{tabular}{ll}
\hline Goodness of Fit Index & Cut-Off Value \\
\hline$X^{2}$ Chi Square & $\leq$ Chi Square table \\
Probability & $\geq .050$ \\
RMSEA & $\leq .080$ \\
GFI & $\geq .900$ \\
AGFI & $\geq .900$ \\
CMIN/DF & $\leq 2.000$ \\
TLI & $\geq .950$ \\
CFI & $\geq .950$ \\
\hline
\end{tabular}

\section{RESULT AND DISCUSSION \\ Results \\ Test of Model Assumption}

In this study, tests of model assumption used are normality and outlier tests. Test of normality data was conducted by using score of critical ratio skewedness values of \pm 2.58 with .05 significance level (5\%). Data are distributed normally if the score of critical ratio skewedness is below \pm 2.58 . The result of data normality test is shown in Table 4.

Tabel 4. Assessment of Normality

\begin{tabular}{lrrrrrr}
\hline Variable & Min & Max & Skew & c.r. & Kurtosis & c.r. \\
\hline SA2 & 19.00 & 48.00 & -.204 & -1.122 & -.076 & -.208 \\
SA1 & 19.00 & 44.00 & -.170 & -.932 & .164 & .450 \\
TP1 & 7.00 & 28.00 & -.121 & -.662 & -.548 & -1.504 \\
TP2 & 20.00 & 80.00 & -.185 & -1.019 & -.518 & -1.424 \\
TP3 & 1.00 & 4.00 & -.056 & -.308 & -.424 & -1.164 \\
TP4 & 6.00 & 24.00 & .247 & 1.354 & -.372 & -1.022 \\
SL1 & 3.00 & 12.00 & .002 & .013 & -.970 & -2.263 \\
SL2 & 4.00 & 16.00 & -.099 & -.545 & -.914 & -2.384 \\
SL3 & 2.00 & 8.00 & -.123 & -.674 & -.669 & -1.838 \\
SL4 & 3.00 & 12.00 & -.329 & -1.806 & -.587 & -1.612 \\
SL5 & 3.00 & 12.00 & .002 & .010 & -.939 & -2.451 \\
IL1 & 4.00 & 16.00 & -.129 & -.707 & -.217 & -.597 \\
TL1 & 2.00 & 8.00 & -.336 & -1.844 & -.227 & -.623 \\
TL2 & 4.00 & 16.00 & -.325 & -1.785 & -.234 & -.643 \\
TL3 & 3.00 & 12.00 & -.095 & -.520 & -.390 & -1.071 \\
TL4 & 3.00 & 12.00 & -.387 & -2.123 & .211 & .580 \\
TL5 & 4.00 & 16.00 & -.375 & -2.059 & -.501 & -1.375 \\
IL2 & 3.00 & 12.00 & .004 & .021 & -.199 & -.546 \\
IL3 & 2.00 & 8.00 & -.126 & -.695 & -.353 & -.970 \\
IL4 & 1.00 & 4.00 & -.393 & -2.160 & .666 & 1.830 \\
IL5 & 1.00 & 4.00 & -.148 & -.812 & -.277 & -.762 \\
IL6 & 3.00 & 12.00 & .072 & .393 & -.393 & -1.080 \\
Multivariate & & & & 14.852 & 2.521 \\
\hline & & & & & &
\end{tabular}


From Table 4, we know that no score of critical ratio (C.R) for skewedness and kurtosis for each indicator above \pm 2.58 . Thus we could come to conclusion that data are normallydistributed on univariate level. Furthermore, on line of multivariate kurtosis, it is shown that score of C.R is $2.521(< \pm 2.58)$. Therefore, we can draw conclusion that the data are distributed normally at multivariate level and it is valid and might be used for further analysis.

\section{Outliers Test}

Multivariate outlier is taken by observing score of Malahanobis distance. Then, score of malahanobis distance is compared to score of chi-square. Multivariate outlier problem occurs if Malahanobis distance score is higher than chi-square ( $\geq$ chi-square). Regarding the requirement, chi-square score obtained in this study is 158,494 and the highest score of Malahanobis distance is 58,452 . Then, we come to conclusion that no multivariate outlier occurs and therefore data in this study is valid and might be used for further analysis. Malahanobis distance score is presented in Table 5.

Table 5. Result of Outlier Test

\begin{tabular}{llcc}
\hline $\begin{array}{l}\text { Observation } \\
\text { Number }\end{array}$ & $\begin{array}{l}\text { Mahalanobis } \\
\boldsymbol{d} \text {-squared }\end{array}$ & $\boldsymbol{p} \mathbf{1}$ & $\boldsymbol{p} \mathbf{2}$ \\
\hline 178 & 58.452 & .000 & .007 \\
155 & 54.078 & .000 & .011 \\
160 & 51.735 & .000 & .016 \\
$\ldots \ldots$ & $\ldots \ldots$ & $\ldots \ldots$ & $\ldots \ldots$ \\
$\ldots \ldots$ & $\ldots \ldots$ & $\ldots \ldots$ & $\ldots \ldots$ \\
$\ldots \ldots$ & $\ldots \ldots$ & $\ldots \ldots$ & $\ldots \ldots$ \\
179 & 19.321 & .625 & .987 \\
4 & 19.314 & .626 & .982 \\
\hline
\end{tabular}

\section{Evaluating the Measurement Model}

Validity of measurement model depends on determination of goodness of fit level that may be accepted for a good model and on the availability of specific evidence of construct validity. To evaluate the validity of measurement model, then tests on construct validity including convergent and discriminant validity were conducted. Variables of study were measured by using 22 indicators. Model of convergent validity is evaluated by applying Confirmatory Factor Analysis (CFA) using AMOS 24. Indicators with loading value $\geq .5$ were also tested. AVE (Average Variance Extracted) measurement must be $\geq .5$. Reliability was measured based on Composite Reliability (CR) that should be more than $(>.70)$ each. Table 6 shows that convergent validity and reliability are adequate because loading factor, CR and AVE fulfils the requirement and are significant. Based on Goodness of Fit indices shown in Table 7, we can see that all indexes fulfil the predetermined criteria, which are $\chi^{2}=158.394$; $\mathrm{RMSEA}=.046$; $\mathrm{GFI}=.930 ; \mathrm{AGFI}=.913 ; \mathrm{CMIN} / \mathrm{DF}=1.774 ;$ $\mathrm{TLI}=.963 ; \mathrm{CFI}=.968$.

Table 6. Results of the Measurement Model

\begin{tabular}{lcccc}
\hline Factor & $\begin{array}{l}\text { Item } \\
\text { Code }\end{array}$ & Loading & AVE & CR \\
\hline Instructional & & & & \\
leadership & IL1 & .921 & .751 & .947 \\
& IL2 & .893 & & \\
& IL3 & .938 & & \\
& IL4 & .842 & & \\
& IL5 & .780 & & \\
IL6 & .814 & & \\
Transformational & & & & \\
leadership & TL1 & .889 & .785 & .948 \\
& TL2 & .853 & & \\
& TL3 & .922 & & \\
& TL4 & .899 & & \\
Spiritual & TL5 & .864 & & \\
leadership & SL1 & .852 & .696 & .919 \\
& SL2 & .830 & & \\
& SL3 & .797 & & \\
Teacher's & SL4 & .774 & & \\
performance & TL5 & .912 & & \\
& TP1 & .763 & .728 & .914 \\
& TP2 & .881 & & \\
Student & TP3 & .839 & & \\
achievement & TP4 & .922 & & \\
& SA1 & .834 & .759 & .863 \\
Note: $N=181 ;$ AVE $=$ Average & .907 & & \\
CR= Coniance Extracted; & & \\
\hline
\end{tabular}

Table 7. The Fit Indices of the Model

\begin{tabular}{|c|c|c|c|}
\hline $\begin{array}{l}\text { Goodness of Fit } \\
\text { No. Indices }\end{array}$ & $\begin{array}{c}\text { Result of } \\
\text { Model Test }\end{array}$ & $\begin{array}{c}\text { Cut-Off } \\
\text { Value }\end{array}$ & $\begin{array}{l}\text { State- } \\
\text { ment }\end{array}$ \\
\hline 1. $X^{2}$ Chi Square & 158.394 & $\leq 170.114$ & Good \\
\hline 2. Probabilityy & .054 & $\geq .050$ & Good \\
\hline 3. RMSEA & .046 & .080 & Good \\
\hline 4. GFI & .930 & .900 & Good \\
\hline 5. AGFI & .913 & .900 & Good \\
\hline 6. CMIN/DF & 1.774 & 2.000 & Good \\
\hline 7. TLI & .963 & .950 & Good \\
\hline 8. CFI & .968 & .950 & Good \\
\hline
\end{tabular}




\section{Interpretation of Structural Model}

Based on the result of evaluation model stated above, the next step that must be conducted is model interpretation. Figure 2 shows the result of SEM test by using AMOS 24 application. The result of hypothesis test is presented in Table 8 . The model should be interpreted to find out the magnitude of direct or indirect contribution as presented in Table 9.
Based on the results of the research analysis, the research hypothesis proposed in the study is supported by field data, because the $p$ value is $<.050$, which means statistically that the better the implementation of instructional, transformational, and the spirituality leadership of the principal can improve teacher performance, furthermore the principal's leadership and teacher's performance determines the maximum learning success of students.

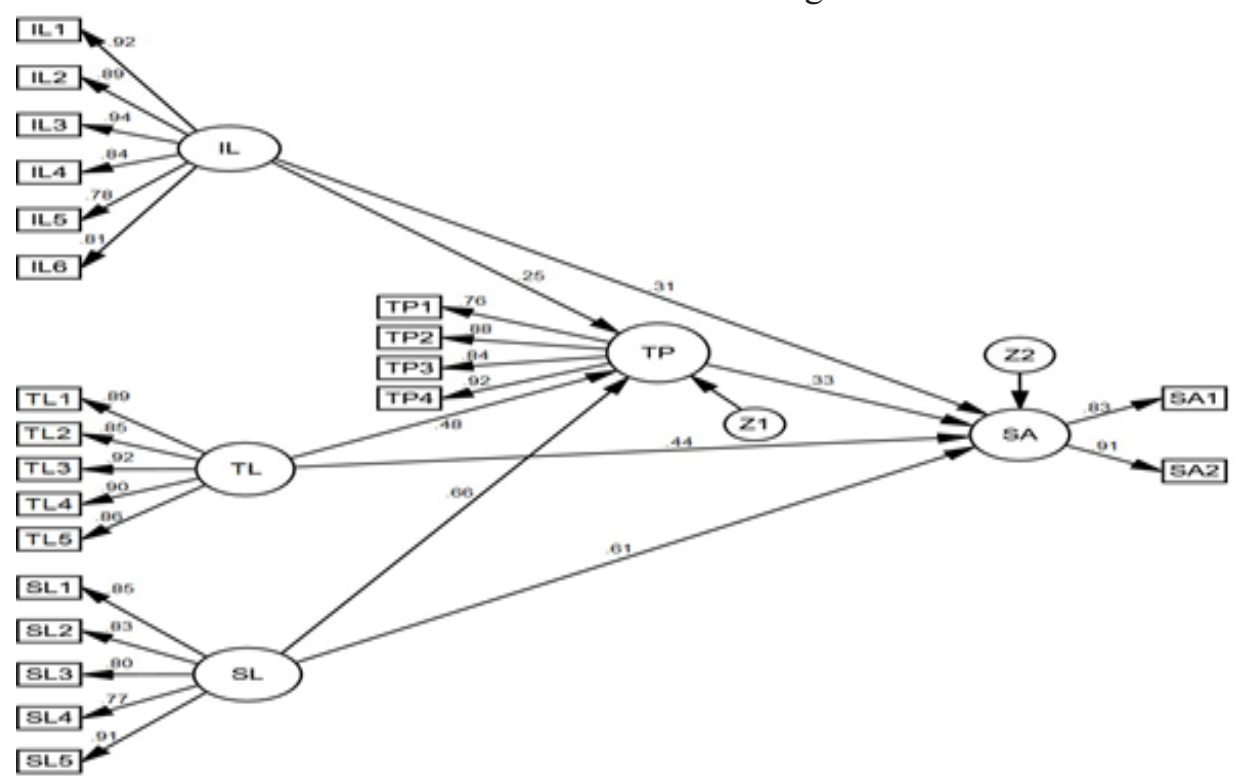

Figure 2. Result of SEM Test

Table 8. Result of Hypothesis Test

\begin{tabular}{llccc}
\hline Variable & Hypothesis & $\boldsymbol{p}$ value & $\begin{array}{c}\text { Cut of } \\
\text { Value }\end{array}$ & Conclusion \\
\hline $\mathrm{IL} \rightarrow \mathrm{TP}$ & $\begin{array}{l}\text { H0: There is an effect of IL variable on TP } \\
\text { H1: there is no effect of IL variable on TP. }\end{array}$ & .002 & .050 & H1 is accepted \\
$\mathrm{TL} \rightarrow \mathrm{TP}$ & $\begin{array}{l}\text { H0: There is an effect of TL variable on TP } \\
\text { H1: There is no effect of TL on TP }\end{array}$ & .000 & .050 & H1 is accepted \\
$\mathrm{SL} \rightarrow \mathrm{TP}$ & $\begin{array}{l}\text { H0: There is an effect of SL variable on TP } \\
\text { H1: There is no effect SL variable on TP }\end{array}$ & .000 & .050 & H1 is accepted \\
$\mathrm{IL} \rightarrow \mathrm{SA}$ & $\begin{array}{l}\text { H0: There is an effect of IL variable on SA } \\
\text { H1: There is no effect IL variable on SA }\end{array}$ & .000 & .050 & H1 is accepted \\
$\mathrm{TL} \rightarrow \mathrm{SA}$ & $\begin{array}{l}\mathrm{H} 0: \text { There is an effect of TL variable on SA } \\
\text { H1: There is no effect TL variable on SA }\end{array}$ & .000 & .050 & $\mathrm{H} 1$ is accepted \\
$\mathrm{SL} \rightarrow \mathrm{SA}$ & $\begin{array}{l}\text { H0: There is an effect of SL variable on SA } \\
\text { H1: There is no effect SL variable on SA }\end{array}$ & .000 & .050 & H1 is accepted \\
$\mathrm{TP} \rightarrow \mathrm{SA}$ & $\begin{array}{l}\text { H0: There is an effect of TP variable on SA } \\
\text { H1: There is no effect TP variable on SA }\end{array}$ & .000 & .050 & H1 is accepted \\
\hline
\end{tabular}

Table 9. Summary of Direct and Indirect Effect Inter Variables of Study

\begin{tabular}{|c|c|c|c|c|}
\hline \multirow{2}{*}{ No. } & \multirow{2}{*}{ Variable } & \multicolumn{2}{|c|}{ Effect } & \multirow[b]{2}{*}{ Total } \\
\hline & & Direct & Indirect & \\
\hline 1. & $\mathrm{IL} \rightarrow \mathrm{TP}$ & .252 & - & .252 \\
\hline 2. & $\mathrm{TL} \rightarrow \mathrm{TP}$ & .480 & - & .480 \\
\hline 3. & $\mathrm{SL} \rightarrow \mathrm{TP}$ & .659 & - & .659 \\
\hline 4. & $\mathrm{IL} \rightarrow \mathrm{SA}$ & .314 & .083 & .397 \\
\hline 5. & $\mathrm{TL} \rightarrow \mathrm{SA}$ & .444 & .157 & .601 \\
\hline 6. & $\mathrm{SL} \rightarrow \mathrm{SA}$ & .613 & .216 & .829 \\
\hline 7. & $\mathrm{TP} \rightarrow \mathrm{SA}$ & .328 & - & .328 \\
\hline
\end{tabular}




\section{Discussion}

\section{The Effect of Instructional leadership on Teacher Performance and Students Achievement}

Principals take crucial role in improving the quality of students' achievement (Garza, Drysdale, Gurr, Jacobson, \& Merchant, 2014; Lee \& Chiu, 2017; du Plessis, 2014). The findings of this study show that instructional leadership of principles gives direct effect on students' achievement. Principal also influences students' achievement through his support to the teachers (Heaven \& Bourne, 2016; Lunenburg, 2010; Neumerski, 2013). It is in line with this study findings showing that principle leadership gives direct effect on teachers' performance and gives indirect effect on students' achievement through teachers' performance. Principal leadership also influences school environment and instructional organization related to students' achievement (Dutta \& Sahney, 2016; Mestry, MoonsammyKoopasammy, \& Schmidt, 2014). Effective leadership of principal occurs when he observes and discusses students' learning progress with teachers (Burroughs, Gardner, Lee, Guo, Touitou, Jansen, \& Schmidt, 2019; Ismail, Don, Husin, \& Khalid, 2018; Usman, 2015). Furthermore, as instructional leadership, principal should be able to motivate teachers to work together to improve the quality of instruction (Harris, Jones, Cheah, Devadason, \& Adams, 2017; Kalman \& Arslan, 2016).

These findings confirm theoretical review and previous study findings in which teachers' performance functions as mediating variable on the effect of instructional leadership of principal on students' achievement (Alam \& Ahmad, 2017; Devos, Tuytens, \& Hulpia, 2014; Vanblaere \& Devos, 2016). Positioning principal as instructional leadership turns to be significant need for all to improve quality of instruction (Bendikson et al., 2012; Pan et al., 2015). It shows that instructional leadership of principal plays important role in improving students' achievement and that principal should take active participation in instructional process, and should guide teachers during instruction and nurtures the process in order to achieve better achievement on the part of students (Msila, 2013; Pina, Cabral, \& Alves, 2015).
Transformational Leadership and its Effect on Teachers' Performance and Students' Achievement

One way to improve students' achievement is by improving the quality of school leadership (Heystek \& Emekako, 2020; Leithwood, Harris, \& Hopkins, 2008). Several previous studies show that principal gives significant effect on students' achievement (Leithwood et al., 2008; Zheng, Li, Chen, \& Loeb, 2017). Successful leaders are those who are able to plan for systematic transformation and facilitate effective instruction in learning organization (Hallinger, 2011; Wiyono, 2017). Kin et al. (2018) claims that transformational leadership competence of principal gives significant effect on teachers' performance.

Study conducted by Kin et al. (2018) implies that if principal equip themselves with adequate transformational leadership competence, teachers' believe on transformation toward high quality performance may also be improved. Teachers' belief on transformation gives significant effect on their attitude toward transformation. The stronger teacher believes, the better their attitude improvement toward transformation. Therefore, improving teachers' belief on transformation is an effective way to improve students' achievement (Drysdale, Bennet, Murakami, Johansson, \& Gurr, 2014; Heystek \& Emekako, 2020). Transformational leadership of principal is crucial for improving teachers' attitude toward transformation (Kin et al., 2018; Wiyono, 2017). The findings are in line with this study finding showing that transformational leadership of principals influences teachers' performance.

The finding of this study also shows that transformational leadership of principal gives indirect effect on students' achievement through teachers' performance. Transformational leadership has more extensive moral objectives and it functions to maintain transformation process, to nurture relations, to share knowledge and to set vision and context in order to create coherence in organization (Hidayat \& Wulandari, 2020; Hutton, 2017; Tang et al., 2014). Then, principal should be resourceful to face transformation (Fullan \& Watson, 2000). Principal does not drive other to solve problems that they already know the solution, but he 
helps them solve problems which has not been solved yet (Drysdale et al., 2014; Jackson \& Marriot, 2012). Basically, it drives the school to start finding new ideas, creating and sharing knowledge which are crucial for solving instructional problems in this modern era.

\section{Spiritual Leadership and its Effect on Teachers' Performance and Students' Achievement}

Spiritual leader set intensive efforts to design working atmosphere in such a way to encourage improvement of teachers' performance (Karadağ, Aksal, Gazy, \& Dagly, 2000) and to nurture teachers' loyalty toward organization (Avolio \& Gardner, 2005; Fry, Matherly, \& Winston, 2007). It is in line with this study findings showing that spiritual leadership influences teachers' performance. Spirituality encourages the emergence of key values on instruction which are crucial for improving teachers' performance and in turn, it will result in the improvement of students' achievement (Fry et al., 2017; Reave, 2005; Sheikh et al., 2019). This study findings shows that there is positive correlation between spiritual leadership of principal and teachers' performance as well as students' achievement. In addition, there is indirect effect of spiritual leadership of principal on students' achievement through teachers' performance. The latter gives positive impact on students' success. Principal might influence students' achievement by monitoring and supervising students, by creating high level of satisfaction toward education and by showing high quality leadership such as providing learning resources for high quality education and by evaluating and improving teacher quality (Karadağ et al., 2020; Phipps, 2012). Spiritual leadership focuses on improvement of teachers' performance and academic achievement of the school (Fry, 2003). Principal's vision will facilitate the improvement of school effectiveness, teachers performance and students' success (Samul, 2020; Al-husseini \& Elbeltagi, 2018).

Spiritual leadership of principal is effective if it gives direct impact on students' achievement and teachers' performance (Fry et al., 2017). It is widely known that there is positive relation between spirituality concept and religion. The source of spiritual leadership is inner spirit or spiritual practice that enables someone to connect and serves for higher cause
(Fry, 2005; Sweeney \& Fry, 2012). Spiritual leadership takes profane dimension on spiritual one. God, the true leader inspires, enlightens, and purifies the soul of His followers by showing guidance and ethical approach. Organization of high performance should have strong harmony between existing personal values of school community, organization and expected values (Fry, 2003; Jeon, Passmore, Lee, \& Hunsaker, 2013).

\section{CONCLUSION}

Principals play crucial role and therefore they are required to be able to encourage, drives, moves, guides, directs and take action to achieve predetermined goals. Based on the study findings, we may draw conclusions that (1) there is direct effect between instructional leadership on teachers' performance, (2) there is direct effect between transformational leadership on teachers' performance, (3) there is direct effect of spiritual leadership on teachers' performance, (4) there is direct effect of instructional on students' achievement, (5) there is direct effect of transformational leadership on students' achievement, (6) there is direct effect of spiritual leadership on students' achievement, (7) there is direct effect of teachers' performance on students' achievement, (8) there is indirect effect of instructional leadership on students' achievement through teachers' performance, (9) there is indirect effect of transformational leadership on students' achievement through teachers' performance, and (10) there is indirect effect of spiritual leadership on students' achievement through teachers' performance.

\section{REFERENCES}

Adair, J. (2007). Develop your leadership skills. London, UK: Kogan Page.

Aiken, L. R. (1985). Three coefficients for analyzing the reliability and validity of ratings. Educational and Psychological Measurement, 45(1), 131-142. https://doi. org/10.1177/0013164485451012.

Al-Husseini, S., \& Elbeltagi, I. (2018). Evaluating the effect of transformational leadership on knowledge sharing using Structural Equation Modelling: The case of Iraqi higher education. International Journal of Leadership in Education, 
21(4), 506-517. https://doi.org/10.1080/1 $\underline{3603124.2016 .1142119}$.

Alam, A., \& Ahmad, M. (2017). The impact of instructional leadership, professional communities and extra responsibilities for teachers on student achievement. International Journal of Educational Management, 31(3), 383-395. https://doi. org/10.1108/IJEM-09-2015-0126.

Avolio, B. J., \& Gardner, W. L. (2005). Authentic leadership development: Getting to the root of positive forms of leadership. The Leadership Quarterly, 16(3), 315-338. https://doi.org/10.1016/j. leaqua.2005.03.001.

Azwar, S. (2012). Reliabilitas dan validitas (4 $4^{\text {th }}$ ed). [Reliability and validity]. Yogyakarta: Pustaka Pelajar.

Bendikson, L., Robinson, V., \& Hattie, J. (2012). Principal instructional leadership and secondary school performance. Research information for teachers, $1(1), 2-8$. https:// doi.org/10.18296/set.0387.

Bezzina, C. (2000). Educational leadership for twenty-first century Malta: Breaking the bonds of dependency. International Journal of Educational Management, 14(7), 299-307. https://doi. org/10.1108/09513540010378950.

Blase, J., \& Blase, J. (2000). Effective instructional leadership. Journal of Educational Administration, 38(2), 130-141. https:// doi.org/10.1108/09578230010320082.

Blome,A.C., \& James, M.E.(1985). The principal as instructional leader: An evolving role. NASSP Bulletin, 69(481), 48-54. https:// doi.org/10.1177/019263658506948107.

Boyatzis, R., \& McKee, A. (2006). Resonant leadership. Personnel Psychology, 59(2), 467-471. https://doi.org/10.1111/j.17446570.2006.00043_4.x.

Brinia, V., Zimianiti, L., \& Panagiotopoulos, K. (2014). The role of the principal's emotional intelligence in primary education leadership. Educational
Management Administration \& Leadership, 42(4 Suppl), 28-44. https:// doi.org/10.1177/1741143213513183.

Brown, M. E., \& Treviño, L. K. (2006). Ethical leadership: A review and future directions. The Leadership Quarterly, 17(6), 595-616. https://doi.org/10.1016/j. leaqua.2006.10.004.

Burroughs, N., Gardner, J., Lee, Y., Guo, Y., Touitou, I., Jansen, K., \& Schmidt, W. H. (2019). Teaching for excellence and equity: Analyzing Teacher Characteristics, Behaviors and Student Outcomes with TIMSS (IEA Research for Education Issue 6). Springer International Publishing.

Bush, T. (2015). Understanding instructional leadership. Educational Management Administration and Leadership, 43(4), 487-489. $\quad$ https://doi. org/10.1177/1741143215577035.

Byrne, B. M. (2016). Structural Equation Modeling with AMOS: Basic concepts, applications, and programming ( $\left.3^{\text {rd }} \mathrm{ed}\right)$. New York, NY: Routledge.

Carpenter, D. (2015). School culture and leadership of professional learning communities. International Journal of Educational Management, 29(5), 682694. https://doi.org/10.1108/IJEM-042014-0046.

Cheng, Y. C., Ko, J., \& Lee, T. T. H. (2016). School autonomy, leadership and learning: a reconceptualisation. International Journal of Educational Management, 30(2), 177-196. https://doi.org/10.1108/ IJEM-08-2015-0108.

Creswell, J. C. (2014). Research design: qualitative, quantitative, and mixed methods approaches ( $4^{\text {th }}$ ed). Thousand Oaks, CA: Sage Publications.

De Lima, T. F. M., \& dos Passos, T. N. (2015). Evaluating a learning management system to support classroom teaching. In Information Resources Management Association. Curriculum Design and Classroom Management: Concepts, 
Methodologies, Tools, and Applications. Harshey, PA: IGI Global, pp. 324-344. https://doi.org/10.4018/978-1-46668246-7.ch019.

Devos, G., Tuytens, M., \& Hulpia, H. (2014). Teachers' organizational commitment: Examining the mediating effects of distributed leadership. American Journal of Education, 120(2), 205-231. https:// doi.org/10.1086/674370.

Drysdale, L., Bennett, J., Murakami, E. T., Johansson, O., \& Gurr, D. (2014). Heroic leadership in Australia, Sweden, and the United States. International Journal of Educational Management, 28(7), 785797. https://doi.org/10.1108/IJEM-082013-0128.

Du Plessis, P. (2014). The principal as instructional leader: Guiding schools to improve instruction. Education as Change, 17(S1), 79-92. https://doi.org/10 $.1080 / 16823206.2014 .865992$.

Dutta, V., \& Sahney, S. (2016). School leadership and its impact on student achievement: The mediating role of school climate and teacher job satisfaction. International Journal of Educational Management, 30(6), 941-958. https://doi.org/10.1108/ IJEM-12-2014-0170.

Fry, L. W. (2003). Toward a theory of spiritual leadership. The Leadership Quarterly, 14(6), 693-727. https://doi.org/10.1016/j. leaqua.2003.09.001.

Fry, L. W. (2005). Introduction to The Leadership Quarterly special issue: Toward a paradigm of spiritual leadership. The Leadership Quarterly, 16(5), 619-622. https://doi. org/10.1016/j.leaqua.2005.07.001.

Fry, L. W., Latham, J. R., Clinebell, S. K., \& Krahnke, K. (2017). Spiritual leadership as a model for performance excellence: A study of Baldrige award recipients. Journal of Management, Spirituality and Religion, 14(1), 22-47. https://doi.org/10 $.1080 / 14766086.2016 .1202130$.

Fry, L. W., Matherly, J. L., \& Winston, B.
(2007). Spiritual leadership as an integrating paradigm for servant leadership. In S. S. Sengupta, \& D. L. Fields (Eds.). Integrating spirituality and organizational leadership. Delhi, India: Palgrave Macmillan, pp. 70-82.

Fullan, M., \& Watson, N. (2000). Schoolbased management: Reconceptualizing to improve learning outcomes. School Effectiveness and School Improvement, 11(4), 453-473. https://doi.org/10.1076/ sesi.11.4.453.3561.

García-Vázquez, E., Crespi, T. D. \& Riccio, C. (Eds.) (2010). Handbook of education, training, and supervision of school psychologists in school and community. New York, NY: Routledge.

Garza, E., Drysdale, L., Gurr, D., Jacobson, S., \& Merchant, B. (2014). Leadership for school success: Lessons from effective principals. International Journal of Educational Management, 28(7), 798811. https://doi.org/10.1108/IJEM-082013-0125.

Ghazali, I. (2011). Model persamaan struktural konsep \& aplikasi dengan program AMOS 19.0. [Structural equation modeling concepts \& applications with the AMOS 19.0 program]. Semarang: Salemba Empat.

Gibson, A. (2014). Principals' and teachers' views of spirituality in principal leadership in three primary schools. Educational Management Administration \& Leadership, 42(4), 520-535. https://journals.sagepub.com/ doi/10.1177/1741143213502195.

Hair, J. F., Black, W. C., Babin, B. J., \& Anderson, R. E. (2010). Multivariate data analysis ( $7^{\text {th }}$ ed). Upper Saddle River, NJ: Pearson Prentice Hall.

Hallinger, P. (2009). Leadership for 21st century schools : From instructional leadership to leadership for learning. China: The Hong Kong Institute of Education.

Hallinger, P. (2011). Leadership for learning: 
Lessons from 40 years of empirical research. Journal of Educational Administration, 49(2), 125-142. https:// doi.org/10.1108/09578231111116699.

Harris, A., Jones, M., Cheah, K. S. L., Devadason, E., \& Adams, D. (2017). Exploring principals' instructional leadership practices in Malaysia: Insights and implications. Journal of Educational Administration, 55(2), 207-221. https:// doi.org/10.1108/JEA-05-2016-0051.

Heaven, G., \& Bourne, P. A. (2016). Instructional leadership and its effect on students' academic performance. Review of Public Administration and Management, 4(3), 1-20. https://www.longdom.org/abstract/ instructional-leadership-and-its-effect-onstudents-academic-performance-15367. html.

Heck, R. H., \& Hallinger, P. (2014). Modeling the longitudinal effects of school leadership on teaching and learning. Journal of Educational Administration, 52(5), 653-681. https://doi.org/10.1108/ JEA-08-2013-0097.

Heystek, J., \& Emekako, R. (2020). Leadership and motivation for improved academic performance in schools in low socioeconomic contexts. International Journal of Educational Management, 34(9), 1403-1415. $\quad$ https://doi.org/10.1108/ IJEM-10-2019-0378.

Hidayat, N., \& Wulandari, F. (2020). The impact of leadership behavior on school performance. Cakrawala Pendidikan, 39(3), 493-506. https://doi.org/10.21831/ cp.v39i3.31005.

Hutton, D. M. (2017). Leadership performance model for the effective school principal. Journal of School Leadership, 27(4), 553-580. https://doi. org/10.1177/105268461702700404.

Hyson, P. (2013). The spirited leader: The potential of spiritual intelligence to improve leadership. International Journal of Leadership in Public Services, 9(3/4), 109-115. https://doi.org/10.1108/
IJLPS-10-2013-0028.

Ismail, S. N., Don, Y., Husin, F., \& Khalid, R. (2018). Instructional leadership and teachers' functional competency across the $21^{\text {st }}$ century learning. International Journal of Instruction, 11(3), 135-152. https://doi.org/10.12973/iji.2018.11310a.

Jackson, K. M., \& Marriott, C. (2012). The interaction of principal and teacher instructional influence as a measure of leadership as an organizational quality. Educational Administration Quarterly, 48(2), 230-258. https://doi. org/10.1177/0013161X11432925.

Jäppinen, A. K., Leclerc, M., \& Tubin, D. (2016). Collaborativeness as the core of professional learning communities beyond culture and context: Evidence from Canada, Finland, and Israel. School Effectiveness and School Improvement, 27(3), 315-332. https://doi.org/10.1080/0 9243453.2015.1067235.

Jeon, K. J., Passmore, D. L., Lee, C., \& Hunsaker, W. (2013). Spiritual leadership: a validation study in a Korean context. Journal of Management, Spirituality \& Religion, 10(4), 342-357. https://doi.org/1 $\underline{0.1080 / 14766086.2013 .801026}$.

Kalman, M., \& Arslan, M. C. (2016). School principals' evaluations of their instructional leadership behaviours: Realities vs. ideals. School Leadership \& Management, 36(5), 508-530. https://doi. org/10.1080/13632434.2016.1247049.

Karadağ, M., Aksal, F. A., Gazi, Z. A., \& Dağli, G. (2020). Effect size of spiritual Leadership: In the process of school culture and academic success. SAGE Open, 10(1), 1-14. https://doi. org/10.1177/2158244020914638.

Kasali, R. (2007). Re code your change DNA membebaskan belenggu-belenggu untuk meraih keberanian dan keberhasilan dalam pembaharuan. [Re-coding your change DNA frees the shackles for courage and success in renewal]. Jakarta: Gramedia Pustaka Utama. 
Kin, T. M., Kareem, O. A., Nordin, M. S., \& Bing, K. W. (2018). Principal change leadership competencies and teacher attitudes toward change: The mediating effects of teacher change beliefs. International Journal of Leadership in Education, 21(4), 427-446. https://doi.org/10.1080/13603124.2016.1 $\underline{272719}$.

Kusmintardjo, K. (2014). Kepemimpinan pembelajaran oleh kepala sekolah. [Learning leadership by the principal]. Manajemen Pendidikan, 24(3), 203-212. http://ap.fip.um.ac.id/?page id=384.

Lee, D. H. L., \& Chiu, C. S. (2017). "School banding": Principals' perspectives of teacher professional development in the school-based management context. Journal of Educational Administration, 55(6), 686-701. https://doi.org/10.1108/ JEA-02-2017-0018.

Leithwood, K., Harris, A., \& Hopkins, D. (2008). Seven strong claims about successful school leadership. School Leadership and Management, 28(1), 27-42. https://doi. org/10.1080/13632430701800060.

Lunenburg, F. C. (2010). The principal as instructional leader. National Forum of Educational and Supervision Journal, 27(4), 1-7. http://www.nationalforum. com.

Mestry, R., Moonsammy-Koopasammy, I., \& Schmidt, M. (2014). The instructional leadership role of primary school principals. Education as Change, 17(S1), 49-64. https://doi.org/10.1080/16823206. 2014.865990.

Min, S., Modeste, M. E., Salisbury, J., \& Goff, P. T. (2016). Heeding the CALL (Comprehensive Assessment of Leadership for Learning) an inquiry into instructional collaboration among school professionals. Journal of Educational Administration, 54(2), 135-151. https:// doi.org/10.1108/JEA-07-2014-0075.

Msila, V. (2013). Instructional leadership: Empowering teachers through critical reflection and journal writing. Journal of
Social Sciences, 35(2), 81-88. https://doi. org/10.1080/09718923.2013.11893149.

Mulyani, H., Meirawan, D., \& Rahmadani, A. (2020). Increasing school effectiveness through principals' peadership and teachers' teaching performance, is it possible? Cakrawala Pendidikan, 39(2), 279-292. $\quad$ https://doi.org/10.21831/ cp.v39i2.28864.

Murakami, E., Garza, E., \& Merchant, B. (2012). When Hispanic students are not expected to succeed: A successful principal's experience.JournalofCasesinEducational Leadership, 15(3), 66-73. https://doi. org/10.1177/1555458912447850.

Neumerski, C. M. (2013). Rethinking instructional leadership, a review: What do we know about principal, teacher, and coach instructional leadership, and where should we go from here? Educational Administration Quarterly, 49(2), 310-347. https://doi. org/10.1177/0013161X12456700.

Nguyen, D., Ng, D., Luo, W., \& Mansor, S. (2020). Exploring the relationships between instructional leadership and teacher competences: Singapore primary school teachers' perceptions. International Journal of Leadership in Education, 1-22. https://doi.org/10.1080/13603124.2020.1 $\underline{731765}$.

Pan, H.-L. W., Nyeu, F.-Y., \& Chen, J. S. (2015). Principal instructional leadership in Taiwan: lessons from two decades of research. Journal of Educational Administration, 53(4), 492-511. https:// doi.org/10.1108/JEA-01-2014-0006.

Parco-Tropicales, M., \& de Guzman,A. B. (2014). A Structural Equation Model (SEM) of the impact of transformational, visionary, charismatic and ethical leadership styles on the development of wise leadership among Filipino private secondary school principals. Asia Pacific Education Review, 15(4), 547-559. https://doi.org/10.1007/ s12564-014-9346-5.

Phipps, K. A. (2012). Spirituality and strategic 
leadership: The influence of spiritual beliefs on strategic decision making. Journal of Business Ethics, 106(2), 177189. https://doi.org/10.1007/s10551-0110988-5.

Pina, R., Cabral, I., \& Alves, J. M. (2015). Principal's leadership on students' outcomes. Procedia - Social and BehavioralSciences, 197,949-954.https:// doi.org/10.1016/j.sbspro.2015.07.279.

Reave, L. (2005). Spiritual values and practices related to leadership effectiveness. The Leadership Quarterly, 16(5), 655-687. $\quad$ https://doi.org/10.1016/j. leaqua.2005.07.003.

Rigby, J. G. (2014). Three logics of instructional leadership. Educational Administration Quarterly, 50(4), 610-644. https://doi. org/10.1177/0013161X13509379.

Samul, J. (2020). Spiritual leadership: Meaning in the sustainable workplace. Sustainability, 12(1), 267-282. https://doi.org/10.3390/ su12010267.

Saunders, M., Lewis, P., \& Thornhill, A. (2016). Research methods for business students ( $7^{\text {th }}$ ed.). Harlow, UK: Pearson Education Limited.

Sheikh, A. A., Inam, A., Rubab, A., Najam, U., Rana, N. A., \& Awan, H. M. (2019). The spiritual role of a leader in sustaining work engagement: A teacher-perceived paradigm. Sage Open, 9(3), 1-15. https:// doi.org/10.1177/2158244019863567.

Stones, E. (2003). Supervision in teacher education: A counselling and pedagogical approach. London: Methuen \& Co. LTD.

Suryadi, \& Tinov, M.Y.T.(2013). Kepemimpinan dalam meningkatkan prestasi belajar siswa. [Leadership in improving student learning achievement]. Jurnal Kebijakan Publik, 4(1), 1-18. https://jkp.ejournal. unri.ac.id/index.php/JKP/article/ view/1327.

Sweeney, P. J., \& Fry, L. W. (2012). Character development through spiritual leadership.
Consulting Psychology Journal: Practice and Research, 64(2), 89-107. https://doi. org/10.1037/a0028966.

Tang, S., Lu, J., \& Hallinger, P. (2014). Leading school change in China: A review of related literature and preliminary investigation. International Journal of Educational Management, 28(6), 655-675. https://doi. org/10.1108/IJEM-07-2013-0114.

Taylor, M., Goeke, J., Klein, E., Onore, C., \& Geist, K. (2011). Changing leadership: Teachers lead the way for schools that learn. Teaching and Teacher Education, 27(5), 920-929. https://doi.org/10.1016/j. tate.2011.03.003.

Usman, H. (2015). Model kepemimpinan instruksional kepala sekolah. [The school principals' instructional leadership model]. Cakrawala Pendidikan, 34(3), 322-333. https://doi.org/10.21831/ cp.v3i3.7338.

Vanblaere, B., \& Devos, G. (2016). Relating school leadership to perceived professional learning community characteristics: A multilevel analysis. Teaching and Teacher Education, 57, 26-38. https://doi. org/10.1016/j.tate.2016.03.003.

Wiyono, B. B. (2007). Metodologi penelitian (Pendekatan kuantitatif, kualitatif, dan action research). [Research methodology (quantitative, qualitative, and action research approaches)]. Malang, Indonesia: Universitas Negeri Malang.

Wiyono, B. B. (2017). The effect of self-evaluation on the principals' transformational leadership, teachers' work motivation, teamwork effectiveness, and school improvement. International Journal of Leadership in Education, 21(6), 705-725. https://doi.org/10.1080/1 $\underline{3603124.2017 .1318960 .}$.

Wong, H. K. (2004). Induction programs that keep new teachers teaching and improving. NASSP Bulletin, 88(638), 41-58. https:// doi.org/10.1177/019263650408863804.

Yakavets, N. (2016). Societal culture and the 
changing role of school principals in the Post-Soviet era: The case of Kazakhstan. Journal of Educational Administration, 54(6), 683-702. https://doi.org/10.1108/ JEA-12-2015-0118.
Zheng,Q.,Li,L.,Chen,H., \&Loeb,S.(2017).What aspects of principal leadership are most highly correlated with school outcomes in China? Educational Administration Quarterly, 53(3), 409-447. https://doi. org/10.1177/0013161X17706152. 